УДК 37.015 .31

DOI https://doi.org/10.26661/2310-4368/2021-3-6

\title{
ДІАГНОСТИКИ I КОРЕКЦІЯ НАВЧАЛЬНИХ ТРУДНОЩІВ: НЕЙРОПСИХОЛОГІЧНИЙ ПІДХІД
}

\author{
Петухова I. O. \\ кандидат педагогічних наук, доцент, \\ в.о. завідувача кафедри психології та соиіологіі \\ Університет державної фіскальної служби України \\ вул. Університетська, 31, Ірпінь, Київська область, Україна \\ orcid.org/0000-0002-5194-5333 \\ petuhova_irina@ukr.net
}

\begin{abstract}
Ключові слова:
навчальні труднощі, діагностика навчальних трудношів, психокорекиія навчальних труднощів, нейропсихологічний підхід у діагностиці і корекиї навчальних труднощів, регуляторна дисграфія, акуститко-артикулячійна дисграфія, зорово-просторова дисграфія.
\end{abstract}

У статті розкриваються сучасні теоретико-практичні питання впровадження методик нейропсихологічної діагностики і корекції дітей початкової школи. Кількість дітей, що має навчальні труднощі, невпинно зростає. Вумовах новоїукраїнськоїшколиакцентподолання цихтруднощів має здійснюватися із опорою на сильні сторони дитини. Серед підходів до діагностики і корекції навчальних труднощів виділяють педагогічний, психологічний, нейропсихологічний. Сутність нейропсихологічного полягає у розвитку несформованих або дефіцитарних зон відповідних відділів головного мозку із опорою на сформовані та/або збережені, що надалізабезпечитьподолання дитиноювідповіднихнавчальних труднощів. У роботі проаналізовано нейропсихологічні причини дисграфії; виділено типологію дисграфії (регуляторна, акустико-артикуляційна, зоровопросторова); представлено типи помилок, які зустрічаються на письмі відповідно до різновиду дисграфії. Встановлено, що такі помилки, як пропуски, дубляжі букв, складів, відносяться до регуляторної дисграфії, тому шляхи корекції варто вибудувати, спираючись на розвиток функцій програмування, регуляції і контролю. Заміна букв діагностує акуститкоартикуляційну дисграфію, іiі корекція має на меті розвиток слухового сприйняття. Труднощі із розташування тексту, початком/серединою рядка визначають зорово-просторову дисграфію, пов'язану з ускладненнями переробки кінестатичної та зорової інформації, тож розвиток зорового та просторового сприймання забезпечить подолання навчальних труднощів, пов'язаних із орієнтуванням дитини у зшиті. Важливе значення має фахова підготовка педагогів нової української школи в контексті здійснення аналізу помилок, яких припускаються учні під час письма. Уміння не просто фіксувати помилки, а аналізувати їх, дозволяє педагогу здійснити первинну діагностику навчальних труднощів і спрямувати дитину до фахівця, який надалі працюватиме над розвитком дефіцитарних зон та корекцію навчальних труднощів. 


\title{
DIAGNOSIS AND CORRECTION OF LEARNING DIFFICULTIES: NEUROPSYCHOLOGICAL APPROACH
}

\author{
Petukhova I. O. \\ Candidate of Pedagogical Sciences, Associate Professor, \\ Acting Head of the Department of Psychology and Sociology \\ University of the State Fiscal Service of Ukraine \\ University str., 31, Irpin, Ukraine \\ orcid.org/0000-0002-5194-5333 \\ petuhova_irina@ukr.net
}

\begin{abstract}
Key words: learning difficulties, diagnostics of learning difficulties, psychocorrection of learning difficulties, neuropsychological approach in diagnosis and correction of learning difficulties, regulatory dysgraphia, acousticarticulatory dysgraphia, visualspatial dysgraphia.
\end{abstract}

\begin{abstract}
The number of children with learning difficulties is constantly growing. In the context of the new Ukrainian school, the emphasis should be on overcoming these difficulties based on the child's strengths. Among the approaches to the diagnosis and correction of learning difficulties are pedagogical, psychological, neuropsychological. The essence of neuropsychology is the development of unformed areas of the relevant parts of the brain based on the formed and / or preserved, which will further ensure that the child overcomes the relevant learning difficulties. The neuropsychological causes of dysgraphia are analyzed in the work; the typology of dysgraphia (regulatory, acousticarticulatory, visual-spatial) is highlighted; the types of errors that occur in writing according to the type of dysgraphia are presented. It is established that such errors as omissions, duplications of letters, syllables belong to the regulatory dysgraphia, so the ways of correction should be built based on the development of programming, regulation and control functions. Letter replacement diagnoses acoustic-articulatory dysgraphia, its correction is aimed at the development of auditory perception. Difficulties in the location of the text, the beginning / middle of the line determine the visual-spatial dysgraphia associated with complications of processing kinestatic and visual information, so the development of visual and spatial perception will overcome the learning difficulties associated with orienting the child in stitching. The professional training of teachers of the new Ukrainian school is important in the context of the analysis of mistakes made by students during writing. The ability not just to record errors, but to analyze them, allows the teacher to make a primary diagnosis of learning difficulties and refer the child to a specialist who will further work on the development of deficient areas and correction of learning difficulties.
\end{abstract}

Постановка проблеми. Інклюзивна освіта на сьогодні стала одним із пріоритетних напрямів державної освітньої політики в Україні. Перехід до неї зумовлений міжнародно-правовими зобов'язаннями, які передбачають обов'язок держави забезпечити інклюзивну освіту на всіх рівнях на підставі рівних можливостей усіх суб'єктів освітнього процесу. Парадигма цього переходу передбачає відхід від медичної і спрямованість на соціальну модель сприйняття людини, що змінює акцент із «обмежень» на «адаптацію» особистості до умов соціуму. Важливою складовою частиною інклюзивного середовища, крім створення фізичних умов, постають соціальні умови (якість взаємодії між учасниками освітнього процесу, формування толерантності та поваги) та відповідна якісна підготовка педагогічних кадрів у контексті ефективної взаємодії із різними категоріями дітей із ООП, чисельність яких щороку збільшується. Так, відповідно до даних Міністерства освіти і науки України у період із 2015/2016 н. р. по 2019/2020 н. р. кількість осіб із ООП, що здобували освіту в інклюзивних класах закладів загальної середньої освіти, зросла у 7 разів (з 2700 осіб з ООП до 19345 осіб з ООП [1]. Для успішної роботи 3 дітьми 3 особливими освітніми потребами вчитель і асистент мають знати причини відставання, усвідомлювати важливість принципів «компенсаторності» та «заміщуючого онтогенезу» як здатності у процесі формування 
знань і вмінь опиратися на менш ушкоджені та/ або збережені ланки особистості, вміти фіксувати увагу на досягненнях, проявляти оптимізм, підтримувати віру у можливості дитини. Окремим важливим умінням фахівців, які працюють в інклюзивному класі, $є$ вміння здійснювати первинну психологічну діагностику навчальних труднощів дітей із ООП.

Проблематиці діагностики і корекції навчальних труднощів у дітей молодшого шкільного віку приділили особливу увагу А. Лурія [9], А. Ануфрієв [2], Т. Ахутіна [3,4], Л. Кондратенко [7], Н. Пилаєва [4,10], А. Семенович [11], А. Сиротюк [12], Є. Хомська [13], Л. Цвєткова [14] та ін. Так, А. Лурія перевагу надавав нейропсихологічній діагностиці, корекції, створивши «батарею» тестів, яка дозволяє оцінити стан основних вищих психічних функцій, визначити зону ураження мозку, виявити форми порушення. У сучасній психологічній науці і практиці методи А. Лурії відносять до інструментів клінічної нейропсихологічної діагностики, які дозволяють вивчити особливості перебігу та розвитку таких пізнавальних процесів, як: мова, мислення, пам'ять, та основних навчальних умінь: читання, письмо, рахунок [9]. Дослідники А. Ануфрієв, С. Костроміна систематизували навчальні труднощі, узагальнили психодіагностичний інструментарій, спрямований на визначення причин, що лежать y їх основі, представили перелік корекційних вправ на розвиток різноманітних елементів психіки дитини [2]. Л. Цвєткова узагальнила психологічні та нейропсихологічні закономірності порушення вищих психічних функцій, розробила наукові засади корекції психічних функцій засобами відновлюваного навчання [11]. Т. Ахутіна дослідила особливості розвитку мовлення, зосередила увагу на діагностиці, корекції, профілактиці труднощів дитини у навчанні, розробила систему розвивального навчання навичок програмування та контролю «Числовий ряд» [3; 4]. Л. Кондратенко систематизувала методики диференціальної діагностики проблем, пов'язаних із розумовим розвитком, навчанням й вихованням дітей молодшого шкільного віку [7]. Вітчизняні дослідники А. Шевцов, О. Ільїна розкрили сучасні теоретичні та практичні питання застосування методик нейропсихологічної корекції розвитку дітей із психофізичними порушеннями [15].

Мета статті полягає у визначенні нейропсихологічних причин навчальних труднощів у дітей шляхом аналізу учнівських письмових робіт; систематизації психокорекційних методів, спрямованих на розвиток відповідних психічних функцій, корекція яких сприятиме подальшому формуванню відповідних навчальних навичок.
Виклад основного матеріалу дослідження. Нейропсихологія як фундаментальна наука про мозок може дати відповідь на питання сучасної педагогіки щодо закономірностей психомоторного, когнітивного та емоційного розвитку особистості школяра, надати фундаментальне обгрунтування методам і підходам, які застосовуються у роботі з дітьми, сприяти розробці рекомендацій для коригування дефектів розвитку і труднощів у навчанні [15]. Відповідно до загально-функціональної моделі (А. Лурія) мозок розділений на три основні блоки, які мають власну структуру i роль у психічному функціонуванні. За нормального розвитку кожна окремо взята психічна функція забезпечується узгодженою роботою трьох функціональних блоків [9]. Нагадаємо, що перший блок забезпечує регуляцію рівня активності глибинних підкірково-стволових структур, його основна функція полягає у регуляції змін активації мозку. Наслідками порушень роботи першого блоку є знижений тонус кори головного мозку, що призводить до нестійкості уваги, швидкої втомлюваності. Порушення роботи другого блоку прийому, переробки і зберігання інформації, що йде від аналізаторів - призводить до погіршення: слуху (пошкодження скроневої долі), тактильної чутливості (тім'яної долі), зорового сприйняття (потиличної долі). Третій блок - програмування, регуляції і контролю - забезпечує перебіг усвідомленої психічної діяльності. Його ураження даного відділу призводить до порушень опорно-рухового апарату, інертності, стереотипізації, імпульсивності особистості.

Зазвичай перші місяці навчання у школі досить швидко демонструють несформованість у дитини певних психічних функцій, що, у свою чергу, у наближеному майбутньому призводить до навчальних труднощів, у тому числі: дисграфiї (порушення письма), дислексії (порушення читання), дискалькулії (порушення рахунку) [8].

До причин навчальних труднощів відносять:

1) педагогічні (дитина пропустила навчальних матеріал або не зрозуміла його);

2) психологічні (дитина має підвищену тривожність, невпевненість; спостерігається відсутність мотивації тощо);

3) нейропсихологічні (недостатність окремих компонентів різних психічних функцій, зокрема: слабкість процесів програмування, регуляції, контролю, серійної організації рухів i дій (III інформаційний блок); слабкість переробки кінестетичної, слухомовленнєвої, зорової, зорово-просторової інформації (II інформаційний блок); проблеми енергетичного забезпечення діяльності (І інформаційний блок).

Ці труднощі можуть виступати окремо або поєднуватися, тому важливим постає виявлення 
первинних i вторинних труднощів шляхом діагностики. Діагностика навчальних труднощів передбачає індивідуальне нейропсихологічне обстеження дитини, коли фахівець має змогу безпосередньо спостерігати за особливостями навчання, виконання навчальних завдань, поведінки, у тому числі під час перерви; застосування тестових методів; аналізу учнівських зошитів. Особливий інтерес представляє аналіз учнівських зошитів, оскільки саме це дозволяє педагогу здійснити оперативну первинну психологічну діагностику імовірних навчальних труднощів дитини і спрямувати іiі до фахівця, який надалі здійснюватиме психокорекцію.

Для прикладу наведемо аналіз навчальних труднощів письма (дисграфія), які можна визначити, перевіряючи письмову учнівську роботу. Для початку зазначимо, що для того, аби писати (нейропсихологічні основи письма), учню необхідно:

1) бути сконцентрованим, проте не надто збудженим, за що відповідають підкоркові структури головного мозку;

2) поставити собі мету - писати, спланувати текст, який буде написаний, у ході роботи перевіряти себе, за що відповідає передня лобна зона, функції програмування, регуляції і контролю;

3) аналізувати звуки, розрізняти їх (скроневі відділи і слухове сприйняття);

4) упізнавати, розрізняти букви (потиличні відділи і зорове сприйняття).

5) орієнтуватися на аркуші паперу (просторове сприйняття);

6) усвідомлювати моторний образ букви: куди рухається рука під час письма (тім'яний відділ і кінестетичне сприймання);

7) поволі переключатися від одного елементу моторної програми до іншого (задньо лобні відділи: організація рухів і навички переключення) [6].

Якщо не сформований хоча б однин із компонентів вищих психічних функцій, це призведе до порушень у формуванні шкільних навичок, зокрема письма. У таблиці 1 представлений взаємозв'язок особливостей письма 3 різновидами дисграфії.

Первинне виявлення проблем у навчанні, яке може бути здійснено вчителем, який перевіряє навчальні роботи, потребує подальшої корекційної роботи з боку психолога, батьків. Серед підходів до корекції навчальних труднощів прийнято виділяти: педагогічний, психологічний, нейропсихологічний. Останній ставить за мету аналіз стану різних компонентів психічних функцій, кожен із яких пов'язаний iз роботою окремих відділів головного мозку (mім'яна зона: сприйняття інформації, яка іде від тіла; скронева зона: слухова переробка інформації; потилична зона - зорова система; тім'яно-скронево-потилична зона: простір; лобна зона: утримання, контроль, переключення [9]) 3 метою виділення найбільш слабких (які потребують корекції) та найбільш сильних ланок вищих психічних функцій, на які варто опиратися у розвивально-корекційній роботі. Психологічну корекцію навчальних труднощів здійснює фахівець, проте поєднання зусиль у тріаді «вчитель, психолог, батьки» дає швидші та стійкіші результати. У таблиці 2 представимо різновиди корекційних ігор і загальні рекомендації батькам відповідно до труднощів у навчанні із урахуванням принципу «заміщуючого онтогенезу».

Нейропсихологічна корекція психічних, психосоматичних факторів піддається змінам завдяки гнучкій мозковій організації функцій: мови, пам'яті, сприйняття, відчуттів, міжфункціональних процесів та поведінкових форм. Шляхом створення спеціальних належних умов, завдяки пластичності нейробіологічних систем дитини за умов скоординованих зусиль між фахівцями та батьками можна досягти високих результатів у корекції навчальних труднощів.

Таблиця 1

\section{Взаємозв'язок особливостей письма із різновидами дисграфії}

\begin{tabular}{|l|l|}
\hline \multicolumn{1}{|c|}{ Тип помилки на письмі } & \multicolumn{1}{|c|}{ Різновид дисграфії } \\
\hline $\begin{array}{l}\text { Пропуск елементів букв, складів, слів; дубляж букв, складів, слів; } \\
\text { антиципації; контамінація двох слів у одне; пропуск великих букв, } \\
\text { знаків, велика кількість орфографічних помилок за умови знань } \\
\text { дитиною необхідних правил }\end{array}$ & $\begin{array}{l}\text { Регуляторна дисграфія (не сформова- } \\
\text { ність функцій програмування, регуляції і } \\
\text { контролю, IІІ блок) }\end{array}$ \\
\hline $\begin{array}{l}\text { Заміна букв, що передають схожість за звучанням: глухих-дзвінких, } \\
\text { твердих-мяякх; заміна букв, близьких за вимовою }\end{array}$ & $\begin{array}{l}\text { Акустико-артикуляційна дисграфія } \\
\text { (труднощі, обумовлені дефіцитом слухо- } \\
\text { вої інформації ІІ блок, ліва півкуля) }\end{array}$ \\
\hline $\begin{array}{l}\text { Труднощі у знаходженні початку рядка, відступів між словами, } \\
\text { коливання нахилу, натискання, ширини, висоти; заміна схожою за } \\
\text { написанням букви; забування букв, складність переходу від друкова- } \\
\text { ної до письмової букви }\end{array}$ & $\begin{array}{l}\text { Зорово-просторова дисграфія (слабкість } \\
\text { переробки кінестетичної та зорової } \\
\text { інформації ІІ блок, права півкуля) }\end{array}$ \\
\hline $\begin{array}{l}\text { Низька працездатність, швидка втомлюваність, надмірна рухливість, } \\
\text { емоційна нестійкість, особливості моторної сфери, зайві рухи }\end{array}$ & $\begin{array}{l}\text { Проблеми енергетичного забезпечення } \\
\text { діяльності (І блок) }\end{array}$ \\
\hline
\end{tabular}


Таблиця 2

Різновиди корекційних ігор і загальні рекомендації батькам відповідно до труднощів у навчанні з урахуванням принципу «заміщуючого онтогенезу»

\begin{tabular}{|c|c|c|}
\hline Труднощі & Корекційні ігри & Рекомендації батькам \\
\hline \multicolumn{3}{|c|}{ I функціональний блок мозку } \\
\hline 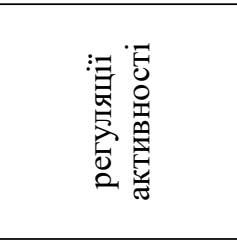 & $\begin{array}{l}\text { Корекційні ігри, спрямовані на розвиток емоційного } \\
\text { інтелекту, підтримку активності дитини, покращен- } \\
\text { ня її самооцінки. } \\
\text { Вправи по формуванню правильного дихання; } \\
\text { масаж, самомасаж; розтяжки; окорухові вправи; } \\
\text { повзання [15]. }\end{array}$ & $\begin{array}{c}\text { Прогулянки з метою кисневого насичен- } \\
\text { ня мозку дитини, вітаміни, спортивні } \\
\text { секції, позитивний емоційний фон, } \\
\text { комунікація усіх членів родини. }\end{array}$ \\
\hline \multicolumn{3}{|c|}{ II функціональний блок мозку } \\
\hline 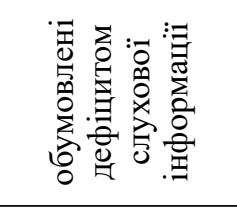 & $\begin{array}{l}\text { Вербальні ігри: «Слова, що відрізняються одним } \\
\text { звуком», «Слова на заданий звук», «Піймай звук», } \\
\text { «Міста», «Карусель зі слів», «Орфографічний фото- } \\
\text { робот», «Шибениця», «Скрабл», «Ерудит» } \\
\text { Шифр слова за малюнками [6]. }\end{array}$ & \multirow{4}{*}{$\begin{array}{l}\text { Слідкувати за якістю власного мовлення. } \\
\text { Слідкувати за розумінням слухових ін- } \\
\text { струкцій дитиною. } \\
\text { Спонукати дитину до пошуку невідомих } \\
\text { слів у інтернеті. } \\
\text { Вести бесіди на довільні теми. } \\
\text { Використовувати вправи на розвиток } \\
\text { фонематичного сприйняття і слухомов- } \\
\text { леннєвої пам'яті. } \\
\text { Розпізнавати звуки природи та оточую- } \\
\text { чого простору, у тому числі - побутові } \\
\text { шуми. }\end{array}$} \\
\hline 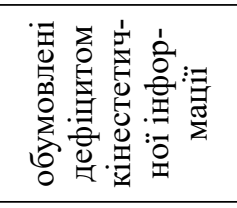 & $\begin{array}{l}\text { Нейропсихологічні вправи по типу: } \\
\text { «Кулак, долонь, ребро» } \\
\text { [3], «Чарівний мішечок» }\end{array}$ & \\
\hline 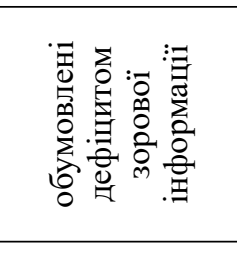 & $\begin{array}{l}\text { «Накладені картинки» } \\
\text { «Зашумлені малюнки» } \\
\text { «Незавершені малюнки» } \\
\text { Ігри на зорову увагу і пам’ять [4]. } \\
\text { Малювання по крапках, домальовування фігур, яких } \\
\text { не вистачає, конструювання та копіювання [15]. } \\
\end{array}$ & \\
\hline 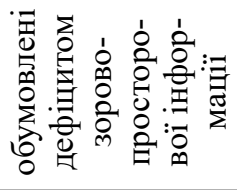 & $\begin{array}{l}\text { Розрізані малюнки } \\
\text { «Намалюй без зразка» } \\
\text { Кубики Кооса [3]. }\end{array}$ & \\
\hline \multicolumn{3}{|c|}{ III функціональний блок мозку } \\
\hline 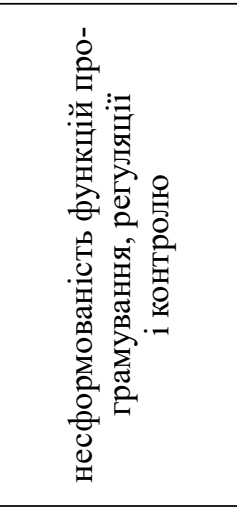 & $\begin{array}{l}\text { Вербальні ігри: «Так-ні не говори», «Розширення } \\
\text { речення» [2]. } \\
\text { Рухові ігри: «Будь ласка», «Роби те, що скажу, а не } \\
\text { те, що покажу», «Руки, ноги, голова», «Класики». } \\
\text { Дидактичні ігри: «Москіто», «Парковка», «Добль», } \\
\text { «Лото» [5]. } \\
\text { Ірги на розвиток робочої (оперативної) пам’яті: за- } \\
\text { пам’ятовування розташування предметів. } \\
\text { Бланкові ігри: «Коректурні проби» (прості, з пере- } \\
\text { ключенням), «Шифровка», «Графічні диктанти», } \\
\text { «Серійні малюнки», «4 зайвий», «Сортування ко- } \\
\text { льорових фігур», Куб Лінка Ірги на розвиток довіль- } \\
\text { ної уваги [7]. }\end{array}$ & $\begin{array}{l}\text { Дії щодо планування і виконання дій } \\
\text { спочатку разом із дорослим, макси- } \\
\text { мально розгорнуто, поступово зводя- } \\
\text { чи до мінімуму спільні дії з акцентом } \\
\text { на самостійне планування і виконання. } \\
\text { Прищеплення правил: гігієни, культури } \\
\text { спілкування, культури гри. Організація } \\
\text { належного середовища. } \\
\text { Режим дня, розклад (із опорою на карт- } \\
\text { ки-підказки). Виконання домашніх } \\
\text { обов'язків. }\end{array}$ \\
\hline
\end{tabular}

Висновки. Таким чином, встановлено, що до нейропсихологічних причин навчальних труднощів у дітей відносять недостатню сформованість окремих компонентів різних психічних функцій; визначено, що первинну нейропсихологічну діагностику може здійснювати учитель шляхом ретельного аналізу учнівських зошитів; представлено типи помилок на письмі та ïx співвідношення із причинами нейропсихологічних порушень; узагальнено перелік психокорекційних вправ відповідно до виявленого порушення, подано рекомендації батькам. До перспектив подальших розвідок відносимо аналіз математичних навчальних труднощів, шляхи ïx первинної нейропсихологічної діагностики i корекції. 


\section{ЛIТЕРАТУРА}

1. Звіт за результатами дослідження щодо доступу дітей з особливими освітніми потребами до інклюзивної освіти у Львівській області. URL : https://mon.gov.ua/storage/app/media/inkluzyvne-navchannya/2021/04/02/Doslidzhennya_dostupu_do_inklyuzyvnoyi_osvity_2_02_04.pdf

2. Ануфриев А.Ф., Костромина С.Н. Как определить трудности в обучении детей. Психодиагностические таблицы. Психодиагностические методики. Коррекционные упражнения. Москва : «Ось-89», 1999. 224 с.

3. Ахутина Т.В. Нейропсихологический анализ ошибок на письме. Нарушения письма и чтения у детей: изучение и коррекция / Под ред. О.А. Величенковой. Москва : Изд-во «Логомаг», 2018. C. 76-95.

4. Ахутина Т.В., Пылаева Н.М. Преодоление трудностей учения: нейропсихологический подход. Санкт-Петербург : Питер, 2008. 320 с.

5. Батарея тестов для обследования детей 6-9 лет. URL : https://drive.google.com/file/d/1U27CPIF3R6TTtNXsSUMSZ5dXGXW3DIxv/view?gcmes $=9635732204 \& \mathrm{gcmlg}=3452274$

6. Выявление дефицитарных зон и работа с ними при коррекции нарушений учебных навыков. URL : https://www.youtube.com/watch?v=Hlsmz_X05_Y

7. Кондратенко Л. Первинне обстеження для виявлення потенційних навчальних труднощів дітей. Психолог. 2004. № 36(132). С. 18-24.

8. Загальна психологія: навчальний посібник / за заг. ред. Р.А. Калениченка, О.Г. Льовкіної, І.О. Пєтухової. Ірпінь : Університет державної фіскальної служби України, 2019. 446 с.

9. Лурия А.Р. Основы нейропсихологии : учеб. пособие для студ. учреждений высш. проф. образования. Москва : Издательский центр «Академия», 2013. 384 с.

10. Пылаева Н.М. Опыт нейропсихологического исследования детей 5-6 лет с задержкой психического развития. Вестник Московского университета. 1995. № 3. С. 37-45.

11. Семенович А.В. Введение в нейропсихологию детского возраста : учебное пособие. Москва : Генезис, 2005. 319 с.

12. Сиротюк А.Л. Нейропсихологическое и психофизиологическое сопровождение обучения. Москва : ТЦ Сфера, 2003. 288 с.

13. Хомская Е.Д. Нейропсихология : 4-е издание. Санкт-Петербург : Питер, 2005. 496 с.

14. Цветкова Л.С., Цветков А.В. Проблема синдрома в нейропсихологии детского возраста. Bonpocы психологии. 2009. № 2. С. 164-170.

15. Шевцов А., Іліна О. Нейропсихологічний підхід до корекції розвиток дітей з порушеннями рухової системи. Актуальні проблеми корекційної освіти: М-во освіти та науки України, Національний педагогічний університет імені Драгоманова, Кам'янець-Подільський національний університет імені Івана Огієнка / за редакцією В.М. Синьов, О.В. Гаврилов. Випуск 5. Кам'янець-Подільський : Медобори-2006, 2015. С. 347-360.

\section{REFERENCES}

1. Zvit za rezul'tatamy doslidzhennya shchodo dostupu ditey z osoblyvymy osvitnimy potrebamy do inklyuzyvnoyi osvity u L'vivs'kiy oblasti [Report on the results of a study on access of children with special educational needs to inclusive education in Lviv region]. Retrieved from: https://mon.gov.ua/storage/app/ media/inkluzyvne-navchannya/2021/04/02/Doslidzhennya_dostupu_do_inklyuzyvnoyi_osvity_2_02_04. pdf [in Ukrainian].

2. Anufryev A.F., Kostromyna S.N. (1999) Kak opredelyt' trudnosty v obuchenyy detey. Psykhodyahnostycheskye tablytsy. Psykhodyahnostycheskye metodyky. Korrektsyonnye uprazhnenyya [How to identify difficulties in children's learning. Psychodiagnostic tables. Psychodiagnostic techniques. Corrective exercises] M. : «Os'-89» [in Russian].

3. Akhutyna T.V. (2018) Neyropsykholohycheskyy analyz oshybok na pys'me [Neuropsychological analysis of writing errors]. M. : Yzd-vo «Lohomah», pp. 76-95. [in Russian].

4. Akhutyna T.V., Pylaeva N.M. (2008) Preodolenye trudnostey uchenyya: neyropsykholohycheskyy podkhod [Overcoming learning difficulties: a neuropsychological approach]. SPb. : Pyter [in Russian].

5. Batareya testov dlya obsledovanyya detey 6-9 let [Battery of tests for examination of children 6-9 years]. Retrieved from: https://drive.google.com/file/d/1U27CPIF3R6TTtNXsSUMSZ5dXGXW3DIxv/view?gcmes $=9635732204 \& \mathrm{gcmlg}=3452274$ [in Russian].

6. Vyyavlenye defytsytarnykh zon y rabota s nymy pry korrektsyy narushenyy uchebnykh navykov [Identification of deficient zones and work with them in the correction of violations of learning skills]. Retrieved from: https://www.youtube.com/watch?v=Hlsmz_X05_Y [in Russian]. 
7. Kondratenko L. (2004) Pervynne obstezhennya dlya vyyavlennya potentsiynykh navchal'nykh trudnoshchiv ditey [Initial examination to identify potential learning difficulties of children] Psykholoh. No36, pp. 18-24. [in Ukrainian].

8. Kalenychenko R.A., L'ovkina O.H., Pyetukhovi I.O. (2019) Zahal'na psykholohiya: navchal'nyy posibnyk. [General psychology: a textbook]. Irpin': Universytet derzhavnoyi fiskal'noyi sluzhby Ukrayiny. [in Ukrainian].

9. Luriya A.R. (2013) Osnovy neyropsikhologii: ucheb. posobiye dlya stud. uchrezhdeniy vyssh. prof. Obrazovaniya [Fundamentals of neuropsychology]. M.: Izdatel'skiy tsentr «Akademiya». [in Russian].

10. Pylayeva N.M. (1995) Opyt neyropsikhologicheskogo issledovaniya detey 5-6 let s zaderzhkoy psikhicheskogo razvitiya [Experience of neuropsychological research of children 5-6 years with mental retardation]. Vestnik Moskovskogo universiteta. No 3. pp. 37-45. [in Russian].

11. Semenovich A.V. (2005) Vvedeniye v neyropsikhologiyu detskogo vozrasta: uchebnoye posobiye [Introduction to childhood neuropsychology]. M. : Genezis [in Russian].

12. Sirotyuk A. L. (2003) Neyropsikhologicheskoye i Psikhofiziologicheskoye soprovozhdeniye obucheniya. [Neuropsychological and psychophysiological support of training] M. : TTS Sfera [in Russian].

13. Khomskaya Y. D. (2005) Neyropsikhologiya: chetvortoye izdaniye. [Neuropsychology]. SPb. : Piter [in Russian].

14. Tsvetkova L. S., Tsvetkov A. V.(2009) Problema sindroma v neyropsikhologii detskogo vozrasta [The problem of the syndrome in childhood neuropsychology]. Voprosy psikhologii. No 2. pp. 164-170 [in Russian].

15. Shevtsov A., Ilina O. (2015) Neyropsykholohichnyy pidkhid do korektsiyi rozvytok ditey z porushennyamy rukhovoyi systemy [Neuropsychological approach to the correction of the development of children with motor disorders]. Aktual'ni problemy korektsiynoyi osvity: $M$-vo osvity ta nauky Ukrayiny, Natsional'nyy pedahohichnyy universytet imeni Drahomanova, Vol. 5. Pp. 347-360 [in Ukrainian]. 